\title{
HOW SPAIN AND CALIFORNIA ADAPT TO SEA LEVEL RISE
}

\author{
Cristina García Fernández \\ Department of Applied Economy $V$ \\ Universidad Complutense de Madrid
}

http://dx.doi.org/10.5209/NOMA.54680

\begin{abstract}
In this article we summarize the main sea level rise impacts and measures that are already taking place in Spain and California. Both are Mediterranean Regions and share many climate change impacts. We will focus on the most relevant sea level rise adaptation measures already being adopted in both areas of study and show how the institutions that have the responsibility for coastal protection and climate adaptation are facing the sea level rise (SLR) issue. Both, Spain and California, have developed a Strategy on Sea Level Rise Adaptation and both are working hard to implement newer and more sustainable measures to adapt to near future climate change impacts from SLR.

First we will describe the main vulnerabilities of each Region facing SLR and present the Institutions in charge of coastal management. Second, we will determine the similarities and differences from SLR impacts in both areas. Finally, we will analyze the adaptation strategies that the coastal institutions are implementing and discuss a mechanism that would help to include all these in a joint effort to support design and implementation of adaptation efforts.
\end{abstract}

Keywords: adaptation to climate change; Sea level rise; impacts and strategies

JEL classification: H41, Q51, Q54

\section{Introduction}

There are five Mediterranean Regions in the world. These regions are likely to suffer the highest rise in temperature and the strongest decrease in annual precipitation. This situation will lead, among other impacts, to increasing desertification, decrease in annual river flow, biodiversity loss and increase in mortality risk during heat waves. Spain and California are both Mediterranean Regions and share many climate change impacts as we will see.

Sea level rise is an important factor to bear in mind in these regions. Populations living in arid and semi-arid zones, low-lying coastal areas, land with water shortages or at risk of overflow or small islands are particularly vulnerable to climate change and, very specifically, to sea 
level rise. Due to increasing population density in sensitive areas, like coastal plains, some regions of Spain and California have become more vulnerable to events such as storms, floods and droughts. Human activities have fragmented and increased the vulnerability of ecosystems, which limit both, their natural adaptation and the effectiveness of the measures adopted.

Both, Spain and California, have developed a Strategy on Sea Level Rise Adaptation and both are working hard to implement newer and more sustainable measures to adapt to present and near future climate change impacts from sea level rise.

In this article we describe the main vulnerabilities of each area of study facing sea level rise and present the Institutions in charge of coastal management. Second, we determine the similarities and differences from SLR impacts in both areas. Finally, we will analyze the adaptation efforts that the coastal institutions are implementing. We conclude with the main results.

\section{State of the Art}

Recent research and climate change analysis indicate (Losada, I, 2014) that the rate of sea level rise will likely accelerate during the coming decades as ocean water continues to warm and expand and as the ice sheets and glaciers of Greenland and West Antarctica break up more rapidly than were previously anticipated.

Caused by both the thermal expansion of seawater and the melting of land-based ice, global sea level rise is expected to accelerate due to increasing rates of ice cap and glacier melting and transfers of more heat from the atmosphere to the oceans (IPCC, 2014). According to the National Research Council Report (NRC, 2012), based on tide gage measurements from around the world, global sea level rose an average of $0.17 \mathrm{~cm}$ per year, for a total of about $18 \mathrm{~cm}$ over the entire 20th century. In comparison, global rates for 1993-2003 were almost double at $0.31 \mathrm{~cm}$ per year, based on precise satellite altimetry measurements and confirmed by tide gage records. Considering the last decade the average rate of sea-level rise has increased to about $3.2 \mathrm{~cm}$.

Since the late 19th century, global sea level has risen by about $1.6 \mathrm{~mm} / \mathrm{yr}$ (Church et al, 2011), whereas its rate did not exceed $0.6 \mathrm{~mm} / \mathrm{yr}$ during the two previous millennia (Kemp et al., 2011). At timescales ranging from decades to centuries, sea level primarily varies because of anthropogenic climate change and its impacts on ice melt and the warming of the oceans (Milne et al., 2009 and Church et al., 2011). As sea level is expected to rise further in the future $(0.5$ to $1 \mathrm{~m}$ by 2100 and possibly more (Church et al., 2013)), there are increasing concerns about its potential future impacts on coastal zones (e.g., Hinkel and Klein, 2009; 
Hinkel et al., 2010; Nicholls and Cazenave, 2010; Nicholls, 2011; Hallegatte, 2012; Hinkel et al., 2012; Hallegatte et al., 2013 and Mimura, 2013).

Population continues to expand in many regions, and people are increasingly at risk from sea-level rise, storms, and flooding, which are exacerbated by global warming (Crossett et al., 2004; Mc Granahan, Balk, and Anderson, 2007; Nicholls, 2010 ).

California has seen a rise in sea-level of approximately $18 \mathrm{~cm}$ over the past century (CO-CAT, 2013). During this time sea-level along most of the coastline has been rising. Coastal flooding, erosion, and salt-water intrusion pose a threat to communities along the California coast and there is compelling evidence that these risks will increase in the future (NRC, 2012).

In Spain, several studies have been focused on the increase in sea level on the Spanish coast (Gutierrez, M and Gutierrez, F, 2014; Losada, I.J., Izaguirre, C., Díaz, P.,2014; OECC, 2015), yielding growth rates between 2-3 $\mathrm{mm}$ / year over the last century with significant variations in the Mediterranean basin caused by regional effects.

Sea-level rise could affect water infrastructure in both regions, including drinking water intakes and wastewater outfalls, and could push saline water into coastal aquifers (Werner, A. D. and Simmons, C. T. (2009)).

\section{The two case study areas: Spain and California}

In this section we describe the main vulnerabilities to SLR that Spain and California are already facing and present the Institutions in charge of coastal management.

\subsection{Spain}

The coastline of the peninsula measures $6,583 \mathrm{~km}$ and borders the Mediterranean Sea and the Atlantic Ocean. The total Spanish coastline, including the islands and the autonomous cities measures $10.000 \mathrm{~km}$.

\subsubsection{Vulnerability and impacts}

Spain has a high overall vulnerability to flooding and erosion. Research studies have indicated that in the case of a widespread SLR the result could be the disappearance of $40 \%$ of the beaches in the east of Cantabria (north) and about $50 \%$ of the Ebro Delta (one of the main rivers) in the region of Cataluña. In addition, significant increases in wave height have been observed along the Cantabrian and Galician (north west) coasts over the past 50 years as well as changes in the direction of the waves particularly in northern Cataluña, leading to an increased risk of flood events along these areas. 
As to the problem of erosion, the Mediterranean coast is said to be most at risk. The total coastline subject to erosion is $11.5 \%$ or $757 \mathrm{~km} 3$. The most vulnerable regions in this respect are Andalucía (South) with erosion along $41 \%$ of its coastline, Cataluña (north east) with $33 \%$ and Valencia (east) with $26 \%$ despite these regions having defense works and artificial beaches along $25 \%$ their coastline. When taking different factors into account (e.g. SLR, erosion, wave height and direction) the regions with the highest exposure to climate change are considered to be Andalucía and Valencia followed by Cataluña, the Baleares (Islands) and Cantabria .

Water scarcity is a significant issue in many regions throughout Spain and climate change is already aggravating the problem, with longer periods of dry weather. Overall, the regions in the south-east of Spain are particularly vulnerable to water shortages due to the hot weather and intensive urbanization of the coastline by the tourism industry and holiday homes. These regions have furthermore an intensive agricultural sector requiring significant irrigation networks. Furthermore, large areas of the Mediterranean are affected by saltwater intrusion. The main cause is groundwater over-abstraction for public water supply, followed by agricultural water demand and tourism-related abstractions.

\subsubsection{Institutions}

The responsibility for coastal protection and climate adaptation is mainly situated at national level. The main institutional framework involved at national level is the Ministry of Agriculture, Food and Environment (Ministerio de Agricultura, Alimentación y Medio Ambiente - MAGRAMA) and its Directorate General for the Sustainability of the Coast and the Sea (Dirección General de Sostenibilidad de la Costa y el Mar). These authorities are responsible for all aspects of the marine and coastal environment within the Maritime Public Domain.

These responsibilities are under the "La Ley de Costas" or Coastal Law. In Spain, the most important law instrument to address the problem of climate change in coastal areas is the Law 2/2013, of May 29, about the protection and sustainable use of coastal areas and the modification of the Coastal Law 22/1988, 28 July.

Furthermore, the Spanish Climate Change Office (Oficina Española de Cambio Climático, OECC), has been designated as responsible body for developing the national climate change policy. The office is responsible for providing advice to governmental institutions, collaborating on initiatives with regard to the fight against climate change and coordinating the different plans, programs and strategies which are being developed to adapt to climate change.

Regional governments have the competency to develop urban planning of the coastal area. When necessary, coastal protection is entrusted by the Spanish Constitution to the national government. 
Funding for coastal protection comes from the national government through the budget of the Directorate-General for the Sustainability of the Coast and the Sea.

Up to date the main updated Plan for SLR is the "Estrategia de Adaptación al Cambio Climático en la costa Española, 2015" (Strategy of Climate Change Adaptation in the Spanish Coast), (MAGRAMA, 2015b).

\subsection{California}

California is situated along the west coast of the United States and has $1.300 \mathrm{~km}$ of coastline. Large El Niño events can raise coastal sea levels by 10 to $30 \mathrm{~cm}$ for several winter months.

\subsubsection{Vulnerability and impacts}

Until mid-century, the most damaging events for the California coast will likely be dominated by large El Niño-driven storm events in combination with high tides and large waves. Eventually, sea level will rise enough that even small storms will cause significant damage, and large events will have unprecedented consequences.

Many aspects of the coastal economy, as well as California's broader economy, are at risk from sea level rise, including coastal-related tourism, beach and ocean recreational activities, transfer of goods and services through ports and transportation networks, coastal agriculture, and commercial fishing and aquaculture facilities.

In addition to potential losses in revenue, it has been estimated that more than a $\$ 100$ billion worth of property is at risk of flooding. This includes seven wastewater treatment plants, commercial fishery facilities, marine terminals, Coastal Highway One, 14 power plants, residential homes, and other important development and infrastructure.

Sea level rise also poses environmental and social justice challenges. This is particularly true for communities that may be dependent upon at-risk industries, already suffering from economic hardship, or which have limited capacity to adapt, including lower-income, linguistically isolated, elderly, and other vulnerable populations.

Sea level rise increases the risk of flooding, coastal erosion, and saltwater intrusion into freshwater supplies, which have the potential to threaten many of the resources that are integral to the California coast, including coastal development, coastal access and recreation, habitats (e.g., wetlands, coastal bluffs, dunes, and beaches), coastal agricultural lands, water quality and supply, cultural resources, community character, and scenic quality. In addition, many possible responses to sea level rise, such as construction of barriers or armoring, can have adverse impacts on coastal resources. For example, beaches, wetlands, and other habitat backed by fixed or permanent development will not be able to migrate 
inland as sea level rises, and will become permanently inundated over time, which in turn presents serious concerns for future public access and habitat protection.

\subsubsection{Institutions}

The potential impacts of sea level rise fall directly within the Coastal Commission's (and coastal zone local governments') planning and regulatory responsibilities under the Coastal Act.

The Coastal Act mandates the protection of public access and recreation along the coast, coastal habitats, and other sensitive resources, as well as providing priority visitor-serving and coastaldependent or coastal-related development while simultaneously minimizing risks from coastal hazards.

The main institutional framework that addresses SLR in California is formed by the:

- California Coastal Commission (CCC) and the San Francisco Bay Conservation and Development Commission, two agencies that regulate land use along the coast and around San Francisco Bay.

- The California Coastal Conservancy, a state agency that works collaboratively to protect and enhance coastal resources. For funding SLR purposes this agency holds the Climate Ready Grants, a program to help advance planning and implementation to lessen the impacts on California's coastal resources.

- Coastal and Ocean Working Group of the California Climate Action Team (CO-CAT), with science support provided by the Ocean Protection Council's Science Advisory Team and the California Ocean Science Trust.

- California OPC (Ocean protective Council): Improving the protection, conservation, restoration, and management of coastal and ocean ecosystems.

\section{Differences in approach and effectiveness for adaptation to SLR between CA and Spain.}

In this section, we determine the similarities and differences from SLR impacts in both areas. Then we will analyze the adaptation efforts that the coastal institutions are implementing.

\subsection{California}

Several factors are contributing to California's unusually high tides: 
- El Niño: El Niño Southern Oscillation' causes changing weather patterns and warmer surface waters in the Pacific, which can lead to increases in sea level.

- Storm Surge: is the abnormal rise in water level caused by a storm, over and above the predicted tide. This rise in water level can cause extreme flooding in coastal areas particularly when storm surge coincides with high tide.

Along the Californian West Coast, sea level is influenced by a number of regional factors, such as decadal (or about a 10 year cycle) ocean and atmospheric circulation patterns and shorter-term heating and cooling effects, such as El Niño in the Pacific Ocean, as well as plate tectonics (NRC 2012).

Because California is geologically active, its coastline has varied topography. Some coastal communities are subject to slow subsidence, some are relatively stable, while others are being gradually uplifted over time (CAT, 2014). This complicates the issue of sea level rise, because in the immediate future, it is relative sea level rise, combined with short-term increases in sea level (from El Niño events, storm surges, and high tides) and large waves that matter to individual communities. Therefore, no one adaptation approach or set of approaches will work for every region.

According to the 2009 California Climate Adaptation Strategy, sea level has risen by an average of about $17,7 \mathrm{~cm}$ along California's $1.300 \mathrm{~km}$ of coastline during this period, contributing to progressive shoreline retreat and coastal cliff, bluff and dune erosion (California Climate Change Center, 2009).

By the year 2100, mean sea level may rise by as much as 1 to $1.4 \mathrm{~m}$ along the coast of California, although these projections are being modified as observations continue to be made and additional data become available. There are also significant year-to-year variations depending on the community. The specific processes or impacts include (CO-CAT, 2013):

1. A continuing rise in local sea level with gradual flooding of low-lying areas in the short-term and permanent inundation in the long-term;

2. The combined effects of short-term sea level increases, high tides and large waves that are often associated with El Niño storm events, which can produce short-term flooding and accelerated rates of erosion;

\footnotetext{
1 El Niño is an irregularly periodical variation in winds and sea surface temperatures over the tropical eastern Pacific Ocean, affecting much of the tropics and subtropics. The warming phase is known as El Niño and the cooling phase as La Niña. Southern Oscillation is the accompanying atmospheric component, coupled with the sea temperature change: El Niño is accompanied with high, and La Niña with low air surface pressure in the tropical western Pacific
} 
3. Increased wave heights and increased or accelerated rates of cliff, bluff or dune retreat.

These impacts are causing a great deal of damage in California. When attending last summer the Fostering Climate Resilient Coastal Communities, a workshop in the University of California in Irvine, and the California Climate Change Symposium 2015, in Sacramento, state agencies like the Ocean Protecting Council or the Coastal Conservancy pointed out the urgent need to face problems like the property damage and infrastructure, the social vulnerability (low income areas, elderly and children), regional vulnerabilities, sea level effect on employment, the need to take into account the insurance issues, etc. As to water problems caused by SLR, they underlined the need of the efficient use of water, wastewater reuse, flood effects on hydro modification, delivering of sediments to the ocean, algae blooms, ocean acidification, etc. Let's have a quick look at these questions.

These events are getting even harder because in California the reduced annual precipitation and the increased duration of the drought is already affecting water supplies, causing drinking water providers to reassess supply plans and consider alternative pricing, allocation and water conservation options.

The higher temperatures are causing precipitation in some areas to increasingly fall as rain rather than snow. Combined with seasonal shifts in springtime snowmelt, areas relying on snowpack to serve as a water 'reservoir', which is the case of many counties in CA, have already the need to develop new plans for ensuring water supplies. In areas with loss of snowpack or less precipitation, water demand may shift to underground aquifers or prompt development of underground storage of treated water.

This is becoming a real problem since saltwater intrusion and increased ground water salinity in coastal aquifers may also increase the permeability of clay liners installed at waste sites, such as landfills, allowing contaminants to spread to nearby properties (Werner and Simmons, 2009). Melting permafrost may allow contaminants to migrate and may cause land shifting and subsidence. These contaminant releases may pose an increased risk of adverse health and environmental impact.

Vulnerable and economically deprived communities may be particularly at risk, both for access to clean and safe water as well as for their ability to respond to emergencies during extreme events.

The city of Los Angeles (LA) 2 is focused on strategies of adaptation due to the severe impacts that SLR is causing on the wastewater plants

\footnotetext{
2 For more information see the document "Sea level Rise vulnerability Study for the City of Los Angeles". Sea Grant, University of Southern California.
} 
(treatment plant), the breakwaters (at the LA and Long Beach Ports), cliff failure and landslides, potable water systems, aquifers, marinas, etc. Sea level rise will potentially exacerbate the damage from these events (Sea Grant, USC, 2013).

\subsection{Spain}

In terms of the legal and administrative organization, Spain has 17 regions of which 10 have part of its territory located on the coast. These communities comprise 24 coastal provinces and 487 municipalities, and the municipal boundary is the main criterion when it comes to integrated management.

Spain is a coastal country with more than $10,000 \mathrm{~km}$ of coastline, an important strategic position, unique oceanographic features, scenic beauty and biological richness. All these factors have made the economic development of Spain always been closely linked to the sea and its shores. Traditionally the main uses have been linked to sea fishing and shipping, but more and more uses and activities are being carried out at sea and coastline such as aquaculture, tourism, energy utilization waves, wind and tides, water desalination, etc.

In Spain, the tourism sector is the most important in terms of flows and income generation. However, the urbanization together with the development of tourism activities make up a set of pressures on the environment, which is particularly concentrated in the Mediterranean, where one third of the Spanish Mediterranean coast has completely built his first kilometer of sea to land.

According to the IPCC (2014) about $50 \%$ of the world population lives in the coastal zone. As is refers to Spain, coastal municipalities, with only $7 \%$ of the territory, home $45 \%$ of the national population.

The past has taught us that the coastal strip and the waterfront are highly dynamic and have a natural variability. However, the excessive urbanization in recent years has changed the coastline, building roads and building on dunes and beach ridges, draining marshes and coastal lagoons and stiffening the coast through dikes and breakwaters. All these actions were made assuming the coastline would remain stable, that extreme flood events would be defined within the historical range and that the sea level would not change.

The MAGRAMA, aware of the importance of making a diagnostic on the possible impacts of climate change on the Spanish coast funded the project Climate Change in the Spanish Coast (C3E) which was coordinated by the Spanish Climate Change Office and implemented by the Institute of Environmental Hydraulics of the University of Cantabria in the framework of the Strategic Action on Energy and Climate Change, National Plan. 
Here we present an overview of some important results being obtained with the methodologies, tools and databases generated under the project cited above. This summary is based on its authors, Losada et al. $(2014)^{3}$ :

- Coastal systems in Spain are especially sensitive to the effects of sea level rise and other factors related to climate change such as rising water surface temperatures, acidification and changes in storm surge.

- Several studies have been focused on the increase in sea level on the Spanish coast, yielding growth rates between 2-3 $\mathrm{mm}$ / year over the last century.

- $\quad$ The rise of mean sea level in the Cantabrian-Atlantic region follows the global average trend between 1.5 and $1.9 \mathrm{~mm} /$ year between 1900 and 2010 and between $2.8 \mathrm{~mm}$ / year and 3, $6 \mathrm{~mm}$ / year between 1993 and 2010. However, there is a greater uncertainty as to the mean sea level in the Mediterranean caused by regional effects.

- $\quad$ The storm surge is one of the main dynamics affecting the Spanish coasts. In the past six decades we have witnessed important changes in both intensity and direction. In the Cantabric Sea there has been a significant increase of up to $0.8 \mathrm{~cm} /$ year in the most intense waves (Sainz de Murieta, 2016) and a decrease in the Mediterranean and Canary Islands.

- The observed impacts attributable to climate change are those that correspond to changes in ocean temperature or acidification. With the available information, the impacts related to flooding and erosion in coastal areas are not attributable to climate change because they are heavily affected by human action.

\section{Adaptation efforts}

A vulnerability assessment is the first step in the process of developing an informed SLR adaptation plan. Assessing the vulnerability to sea level rise needs to consider three factors (Russell et al, 2012): 1] the probable magnitude of SLR and its associated impacts; 2] the sensitivity of the area to sea level rise and future storm and wave impacts and 3] the ability of the region to adapt or respond.

A vulnerability assessment should include an evaluation of the degree of a region's exposure to various shoreline hazards as well as the magnitude of the impact in the case of a significant event (El Niño) that elevates sea level significantly. Adaptation is the adjustment of natural or human systems to actual or expected phenomena or their effects.

3There is also a cartographic display of the entire Spanish coast which allows observing the impacts of climate change. http://www.c3e.ihcantabria.com/. CAMBIO CLIMÁTICO EN LA COSTA ESPAÑOLA: C3E. MAGRAMA. Acción Estratégica de Energía y Cambio Climático. Plan Nacional. Enero 2009-Diciembre 2012. Exp. 200800050084091. 
Once the vulnerability and risk assessments are complete, they can be used as the basis for defining a specific Plan of Action.

A Plan of Action must include the goals. Goals should set desired endpoints by stating the preferred long-term outcomes of adaptation to SLR. The following are examples of goals and measures already in early process of implementation in coastal areas of California (Cal OES, 2013):

1. Relocation of existing infrastructure away from vulnerable areas.

2. Design future public works projects to take into account projections for SLR.

3. Eliminate public subsidies for future development in high hazard coastal areas and prioritize critical public infrastructure for retrofitting and protection.

4. Potential removal of barriers to landward migration.

5. Develop strategic property acquisition programs to discourage development in hazard prone areas and allow inland migration of coastal habitats.

7. Discourage placement of shoreline armoring and encourage sustainable forms of development.

The Spanish coast is primarily focused on the retreat from highly vulnerable areas and relocation of infrastructure, crops, industrial activity and population directly affected. We are implementing a strategy aimed at three types of measures (Losada et al. 2014). The first set is the retreat policies:

- Ease inland migration into marshlands and wetlands favoring setback strategies.

- $\quad$ Prevent future developments In highly vulnerable areas

- Revision of boundaries and application of the Coastal Law.

- Introduce the necessary territorial planning taking into account vulnerability to the effects of climate change.

- In new occupations make conditional grant permits; limited concessions; agreements of relocation and / or demolition.

- $\quad$ phasing out crop subsidies in low coastal areas that could be employed to retreat strategies

- $\quad$ Establish expropriation / compensation strategies

- Tax incentives for the purchase of land for conservation purposes.

A second set of policies is aimed at implementing adaptation strategies. These are based on the conservation of the coastal ecosystem and based on a progressive adaptation management:

- Promote the implementation of an Integrated Coastal Zone Management in which the potential effects of climate change should be included.

- $\quad$ Promote a land use planning in anticipation of climate change. 
- Enter in the design of new coastal infrastructure the effect of climate change.

- $\quad$ Re-evaluate the infrastructure in areas of high vulnerability.

- $\quad$ Promote the introduction of the effect of climate change on the Recommendations of Maritime Works and standards for infrastructure in highly vulnerable areas.

The third set of policies is aimed at the protection of vulnerable areas like population, economic activities, infrastructure and natural resources. They are essentially based on individual or joint application of these two types of defense and are known as rigid and soft typologies. Between the rigid types we can see: dams, walls, barriers, breakwaters, coatings and barriers against saline intrusion. Soft types include beach nourishment, dune restoration, creation of wetlands and marshes, coastal rehabilitation, reforestation, etc.

Another important issue is to consider the timeframe. The timeframe identified for a project is an important consideration for SLR projections and will affect the approach for assessing SLR impacts (CNRA, 2009).

\section{Implementing adaptation}

Once the goals are defined it is time for implementing them. But one of the most important requirements for sustained long-term implementation is scientific credibility. For example, a map that depicts the historic landward migration of a shoreline or bluff edge over time stands as clear evidence that the coastline is not static or stationary, and that it is experiencing a process that will likely be amplified in the future (CNRA, $2014)^{4}$.

Once policies are enacted, measures must also be monitored over time in order to determine their effectiveness, because stakeholders need to know whether the policies are fulfilling their intended purposes (CEMA and CNRA, 2012). This may be challenging initially because the rates of change (millimeters per year of sea level rise or coastline retreat) are still relatively small, and because it is difficult to determine whether increased wave heights or larger storms are due to climate change or just part of the normal range of conditions to be expected. It is of course necessary to ensure that SLR adaptation measures are appropriate for the geographic area and that the measures achieve their intended goals.

The following paragraphs present the main instruments and adaptation efforts related to SLR being developed by several institutions in both areas of study.

4 This kind of data already exists for both areas of study. In the Spanish case see http://www.c3e.ihcantabria.com. For CA you can go to http://tidesandcurrents.noaa.gov/sltrends/index.shtml. 


\subsection{Spain}

Since 2004, the adaptation to climate change has been a priority for Spain, due to the high vulnerability of the Spanish coast towards climate variability. In 2006, the National Plan for Adaptation to Climate Change 5 (PNACC) was approved after an extensive process involving the main institutions in charge of climate change: The Spanish Office for Climate Change ${ }^{6}$ (OECC), the Commission for the Coordination of Climate Change Policies ${ }^{7}$ and National Climate Council 8 .

The PNACC is a framework for coordination between public administrations in the activities of impact assessment, vulnerability and adaptation to climate change in Spain. This National Plan runs through work programs which define the activities to be carried out.

The last Work program (2014-2020) contains prioritized lines of action for different geographic territories like coastal zones and includes the development of the Strategy for Adapting the Coast to the Effects of Climate Change?. This is an ongoing Strategy that will integrate adaptation to climate change in the planning and management of coastal areas and will increase the resilience to climate change and climate variability.

Coastal areas are classified as one of the priority areas of action of this third work program. The effects of climate change projected on the Spanish coast, according to future climate scenarios indicate, among other changes, a gradual warming of water and a patent sea level rise as we move farther to the XXI century.

Moreover, the OECC, through a collaboration agreement with the University of Cantabria elaborated specific technical tools that will support the establishment of climate change policies and action strategies on the Spanish coast.

These studies are divided into three phases. The first one released the Assessment of changes in the Spanish coastal dynamics ${ }^{10}$, which analyses prediction data to estimate the expected changes in coastal dynamics along the XXI century under various climate change scenarios.

In a second phase - Assessment of effects on the Spanish coast - there is an evaluation of the coastline elements that changes in coastal dynamics may cause in natural spaces and human uses of the coastline. Phase 3 - Strategies to climate change in the coast - proposes and evaluates a system of indicators and indexes that provide objective

\footnotetext{
5 Plan Nacional de Adaptación al Cambio Climático (OECC, 2006).

6 Oficina Española de Cambio Climático.

7 Comisión de Coordinación de Políticas de Cambio Climático.

8 Consejo Nacional del Clima.

9 La Estrategia de Adaptación de la Costa a los Efectos del Cambio Climático (MAGRAMA, 2015b)

10 Fase de Evaluación de cambios en la dinámica costera española.
} 
information for the establishment of policies and action strategies to correct and prevent the effects of climate change on the Spanish coast obtained in the second phase.

Subsequently, in 2014, MAGRAMA funded the project called Climate Change in the Spanish Coast (C3E), which diagnoses the effects of climate change across the peninsular Spanish coast and its islands in more detail, and provides the coastal managers a variety of tools in order to integrate these effects on policies and measures of coastal protection.

The results served to finally develop the Strategic Environmental Study for the Environmental Assessment of the Adaptation Strategy to Climate Change of the Spanish Coast (EsAE), (MAGRAMA, 2015a) ${ }^{11}$. This is the result of identifying, describing and evaluating the likely significant effects on the environment derived from the implementation of the Strategy for Adaptation to Climate Change in the Spanish Coast considering reasonable alternatives.

\subsubsection{Funding:}

In Spain the main source of funding is at a European and national levels. The European Commission provides with the Financial Instrument for the Environment and Climate Action (LIFE). It is the only financial instrument of the European Union dedicated exclusively to the environment. LIFE was adopted on 19 March 2014 by a Decision of the European Commission. LIFE Climate Change Adaptation (sub-program for climate action) co-finances action grants "for best practice, pilot and demonstration projects that contribute to supporting efforts leading to increased resilience to climate change; that contribute to the development and implementation of Union policy on climate change adaptation".

This Decision establishes the framework for action for the next four years for the management of the LIFE program 2014-2020. "Adapting to climate change" constitutes a priority area with a budget of $€$ $190,389,591$.

At a national level spain receive funding from MAGRAMA. This materializes in Grants and subsidizes projects and measures at national and regional level in the environmental, food and fisheries sectors. There is specific funding at regional level for climate change adaptation in coastal areas.

\subsection{California}

Using the Coastal Act, the Coastal Commission and local governments have more than four decades of experience managing coastal

11 Estudio ambiental estratégico para la evaluación ambiental de la estrategia de adaptación al cambio climático de la costa española (ESAE). 
development, including addressing the challenges presented by coastal hazards like storms, flooding, and erosion as well as responses to these hazards such as armoring.

California is a leader in the global effort to fight climate change. The state is pursuing a broad, integrated strategy to reduce greenhouse gas emissions and build the foundation for a new clean energy economy. The Safeguarding California Plan (CNRA, 2014) provides policy guidance for state decision makers, and is part of continuing efforts to reduce impacts and prepare for climate risks. This plan, which updates the 2009 California Climate Adaptation Strategy, highlights climate risks in nine sectors in California, discusses progress to date, and makes realistic sector-specific recommendations.

The final report from the NRC, Sea-Level Rise for the Coasts of California, Oregon, and Washington, was released in June 2012. This one was the result of the Executive Order S-13-0812. The State of CA Sea-Level Rise Guidance Document was released in march 2013 and updated with the scientific findings of the 2012 NRC report. The intent of this guidance document is to inform and assist state agencies as they develop approaches for incorporating SLR into planning decisions with the most recent and best available science, as published in the 2012 NRC report.

The California Coastal Commission Draft Sea Level Rise Policy Guidance Public Review Draft, was released in May, 2015. It focuses specifically on how to apply the Coastal Act to the challenges presented by sea level rise through Local Coastal Program (LCP) certifications and updates and Coastal Development Permit (CDP) decisions. It organizes current science, technical, and other information and practices into a single resource to facilitate implementation of the Coastal Act by coastal managers at the state and local level.

\subsubsection{Funding}

There are several Programs in California with funding for SLR issues. They are mainly provided at regional and local levels. The most recent ones are the following:

- Local Coastal Program Local Assistance grants, funded by the California Coastal Commission. This Program provides funds to support local governments in planning for sea-level rise and climate change,

12 "The California Resources Agency, in cooperation with DWR, CEC, California's coastal management agencies, and the OPC, shall request that the National Academy of Sciences (NAS) convene an independent panel to complete the first California Sea Level Rise Assessment Report and initiate, within 60 days after the signing of this Order, an independent sea level rise science and policy committee made up of state, national and international experts". 
and developing new or updating existing Local Coastal Programs (LCP), consistent with the California Coastal Act.

- Local Coastal Program SLR Grant Program, funded by the Ocean Protective Council. The main example for this instrument is the USC Sea Grant Program. The result was the "Sea level Rise vulnerability Study for the City of Los Angeles". Sea Grant, University of Southern California.

- Climate Ready Grants, funded by the Coastal Conservancy (other items included, not only SLR).

\section{Conclusions}

Spain and California are Mediterranean regions with similar sea level rise impacts. Both Regions have experienced a rise in sea-level of approximately $18 \mathrm{~cm}$ over the past century.

Both areas are quite vulnerable to sea level rise. Coastal flooding, erosion, and salt-water intrusion pose a threat to communities along the California and Spain coast. Either in Spain or California, vulnerability varies depending on the region or the community.

Most damaging events for the California coast will likely be dominated by large El Niño-driven storm events in combination with high tides, storm surges and large waves. Eventually, sea level could rise enough that even small storms would cause significant damage. It is the relative sea level rise at any particular location rather than global SLR that matters to individual communities in California. By the year 2100, mean sea level may rise by as much as 1 to 1.4 meters along the coast of California, although these projections are being modified as observations continue to be made and additional data become available.

In Spain it is the storm surge the main dynamics affecting the coasts. The main observed impacts attributable to climate change are those that correspond to changes in ocean temperature or acidification. With the available information, the observed impacts related to flooding and erosion in coastal areas are not specifically attributable to climate change because they are heavily affected by human action, like the 
urbanization, population density, the development of touristic and port activities, etc. In particular, the touristic sector has set a great pressure on the environment, which is particularly concentrated in the Mediterranean coast. In Spain, research studies have indicated that a $0.5 \mathrm{~m} \mathrm{SLR}$ is considered to be a reasonable scenario for Spain by 2100. We can then see that California is expected to suffer more sea elevation for the near future.

Both regions are implementing efforts in developing more and greater funding instruments and resources. Both are developed and rich areas and have the institutions and resources to tackle climate change problems and, more specifically, sea level rise impacts. The difference between Spain and California is only or mainly a question of national or local levels. In Spain, Funding is coming from national institutions, like MAGRAMA, or European instruments, like LIFE. California is basically implementing efforts from local and state agencies and local coastal programs.

Both are involved in measures focused on the protection of vulnerable areas and relocation, conservation of the coastal ecosystem, economic activities, infrastructure and natural resource retreat from highly vulnerable areas. Also both are implementing protective measures on dams, walls, barriers, breakwaters, coatings and barriers against saline intrusion, beach nourishment, dune restoration, creation of wetlands and marshes, coastal rehabilitation,

The reflections showed above leads us to an important general conclusion about adaptation to climate change. We can say that unfortunately not all countries, regions or communities can react to climate change and its impacts at the same level. The adaptive capacity is directly related to the status of natural resources and the level of socio-economic development. Cities and communities within developed countries are more likely to succeed in their efforts towards mitigation and adaptation than the developing world, which means that the degree of urban development might act as a precondition for a successful response to climate change. The latter leaves "people" from developing countries with the overwhelming challenge of dealing with climate change and socio-economic development strategies at the same time.

We must realize that a great part of the developing world is already suffering from severe sea level rise impacts and that without the financial resources and the institutional capacity to comprehensively manage climate change, these countries will pay the price with more urban poverty, water and food scarcity, dissemination of diseases, urban migration or relocation of entire communities, environmental stresses and sea level rise damage. 


\section{Discussion and Results}

We have found out that both Mediterranean regions are already implementing measures that have common goals and objectives.

Either Spanish or California's coastal institutions are working to address the emerging impacts of climate change. As a result of this study we must say that California is recently showing leadership in prioritizing, researching, and developing a broad range of measures for climate change adaptation. California has invested in a range of data, tools, and guidance products in recent years to promote statewide consistency in planning for sea-level rise and more effective responses to related coastal impacts like flooding and erosion. These investments have provided advancing knowledge of climate change and SLR.

But there is still a great deal of work to do. Although both regions have shown many adaptation efforts to face the problem of sea level rise, most of the policies are at an infant state. There is also a lack of a joint effort within the Mediterranean regions to cope with this present unavoidable problem. Bringing new knowledge to bear on complex issues, such as coastal adaptation planning, requires consideration of what new policies and institutions are needed, and how existing policies and institutions can change to be more effective. And it requires thoughtful engagement and negotiation among producers and users of knowledge. As we have seen sea-level rise is expected to increase the severity of coastal flooding and erosion in the coming decades. Adapting to rising seas is among the most challenging issues that coastal decision-makers face, and a lack of adequate training, technical support, and information tailored to their decision making context makes it difficult to effectively manage and plan for this emerging threat. There is still a need for useful information and guidance to plan at multiple levels of government for these anticipated impacts.

One of the difficulties of developing adaptation strategies is to define a baseline, indicators and objectives. Contrary to emission reduction pledges, adaptation needs are very context specific and need to be based on local vulnerabilities. The indicators are difficult to develop because there is still no specific single variable valid across all regions on adaptation with which to measure the type and level of adaptation

Adaptation to SLR is the result of a process involving many interrelated steps and various actors dependent on integrated planning between different municipal departments and allocation of funding for concrete measures. However, the picture with regard to adaptation in the developed world is still scattered, and in many cases, cities, regions and communities are implementing stand-alone measures not linked to a holistic adaptation process.

In order to effectively respond to climate change, global actors at different levels require both a methodology and a tool to help them in 
the decision-making process. The methodology would be able to establish a mechanism to effectively coordinate efforts and set priorities within a human development approach towards climate change. On the other hand, the tool will allow global actors to identify if adaptation or mitigation, or adaptation and mitigation are needed to best cope with climatic variability and its impacts. This tool would enable them to visualize and compare all possible mechanisms in order to make choices and take decisions.

Finally, this article, which is in part the result of my research at UCLA Luskin Center for Innovation will lead us, as the following step, to discuss a mechanism, tool and approach that would help to include all these policies, strategies and measures in a joint effort to support design and implementation of adaptation efforts.

\section{References}

California Climate Change Center, 2009: California Energy Commission Public Interest Energy Research Climate Change Program.

California Natural Resources Agency (CNRA), 2009: California Climate Adaptation Strategy.

California Natural Resources Agency (CNRA), 2014: Safeguarding California: Reducing Climate Risks: An update to the 2009 Adaptation Strategy.

California Emergency Management Agency (CEMA) and CNRA, 2012: California Adaptation Planning Guide.

Cal OES, 2013: State of California Multi-Hazard Mitigation Plan. California Governor's Office of Emergency Services.

CAT, California Climate Action Team, 2014: California Climate Change Research Plan.

Church, J.A; White, N.J; Konikow, L.F; Domingues, C.M ; Rignot, J.M. Gregory, M.R. van den Broeke, A.J. Monaghan, I. Velicogna, 2011: Revisiting the Earth's sea-level and energy budgets from 1961 to 2008 Geophys. Res. Lett., 38 (2011).

Church, J.A; Clark, P.U; Cazenave, A; Gregory, J.M; Jevrejeva, S; Levermann, A. Merrifield, MA; G.A. Milne, R.S. Nerem, P.D. Nunn, A.J. Payne, W.T. Pfeffer, D. Stammer, A.S. Unnikrishnan (2013): Sea-level rise by 2100. Science, 342 (6165) (2013), p. 1445-1445. 
COM(2009) 147/4. Adapting to climate change: Towards a European framework for action. White Paper. Brussels.

CO-CAT, 2013: The Coastal and Ocean Resources Working Group for the Climate Action Team. State Of California Sea-Level Rise Guidance Document, with science support provided by the Ocean Protection Council's Science Advisory Team and the California Ocean Science Trust March 2013 update

Crossett, K. ; Culliton, T.J. ; Wiley, P. , and Goodspeed, T.R. , 2004: Population Trends Along the Coastal United States, 19802008. Silver Spring, Maryland: National Oceanic and Atmospheric Administration, 47P.

European Communities, 2009: The economics of climate change adaptation in EU coastal areas, Summary report.

European Commission, 2013: The EU Strategy on adaptation to climate change.

Gutierrez, M and Gutierrez, F. (Eds)., 2014: Landscapres and Landforms in Spain. University of Zaragoza. Ed. Springer.

Hallegatte, S., 2012: A framework to investigate the economic growth impact of sea level rise. Environ. Res. Lett., 7 (1) (2012)

Hallegatte, C. Green, R.J. Nicholls, J. Corfee-Morlot., 2013: Future flood losses in major coastal cities. Nat. Clim. Chang., 3 (9) (2013), pp. 802-806

Hinkel, J; Klein, R.J.T., 2009: Integrating knowledge to assess coastal vulnerability to sea-level rise: the development of the DIVA tool. Glob. Environ. Chang. Hum. Policy Div., 19 (3) (2009), pp. 384-395.

Hinkel, J; R.J. Nicholls, A.T. Vafeidis, R.S.J. Tol, T. Avagianou., 2010: Assessing risk of and adaptation to sea-level rise in the European Union: an application of DIVA. Mitig. Adapt. Strateg. Glob. Chang., 15 (7) (2010), pp. 703-719

Hinkel, J; S. Brown, L. Exner, R.J. Nicholls, A.T: Vafeidis, A.S. Kebede., 2012. Sea-level rise impacts on Africa and the effects of mitigation and adaptation: an application of DIVA. Reg. Environ. Chang., 12 (1) (2012), pp. 207-224.

IPCC, 2014. Climate Change 2014: Impacts, Adaptation, and Vulnerability. Part A: Global and Sectoral Aspects. Contribution of Working Group II to the Fifth Assessment Report of the Intergovernmental Panel on Climate Change. Cambridge University Press, Cambridge, United Kingdom and New York, NY, USA.

Kemp, A.C; Horton B.P; Donnelly, J.P; Mann, M.E; Vermeer, M; Rahmstorf, S., 2011: Climate related sea-level variations over the past two millennia. Proc. Natl. Acad. Sci. U. S. A., 108 (27) (2011), pp. 11017-11022. 
Losada,I., MAGRAMA, 2004. Efectos en la costa española por efectos del cambio climático.

Losada, I.J., Izaguirre, C., Díaz, P., 2014: Cambio climático en la costa española. Oficina Española de Cambio Climático, Ministerio de Agricultura, Alimentación y Medio Ambiente, Madrid.

McGranahan, G ; Balk, D. , and Anderson, B. , 2007: The rising tide: assessing the risks of climate change and human settlements in low elevation coastal zones.Environment \& Urbanization, 19(1), 1737. [CrossRef].

MAGRAMA, 2015a: Estudio Ambiental Estratégico Para La Evaluación Ambiental De La Estrategia De Adaptación Al Cambio Climático De La Costa Española. Dirección General De Sostenibilidad De La Costa Y Del Mar.

MAGRAMA, 2015b: Estrategia De Adaptación Al Cambio Climático De La Costa Española.

Milne, G.A; Gehrels, W.R; Hughes, C.W; Tamisiea, M.E, 2009: Identifying the causes of sea-level change. Nat. Geosci., 2 (7) 2009.

Mimura, 2013: Sea-level rise caused by climate change and its implications for society. Proc. Jpn. Acad. Ser. B Phys. Biol. Sci., 89 (7) (2013), pp. 281-301.

National Research Council (NRC), 2012: Sea level Rise for the Coasts of California, Oregon and Washington: Past, Present and Future. The National Adad-emies Press, Washington, DC.

Natural Resources Agency (NRA), 2014: Safeguarding California: Reducing Climate Risk, An update to the 2009 California Climate Adaptation Strategy.

Nicholls, R.J., 2010: Impacts and responses to sea-level rise. In: Church, J.A. , Woodworth, P.L. , Aarup, T. , and Wilson, W.S. (eds.), Sea-level Rise and Variability.Chichester, United Kingdom: Wiley-Blackwell, pP. 17-43.

Nicholls, R.J; Cazenave, A., 2010: Sea-level rise and its impact on coastal zones. Science, 328 (5985) (2010), pp. 1517-1520

Nicholls, R.J., 2011: Planning for the impacts of sea level rise. Oceanography, 24 (2) (2011), pp. 144-157.

Oficina Española de Cambio Climático (OECC), 2006: Plan Nacional de Adaptacion al Cambio Climatico (PNACC).

OECC, 2015: La Estrategia de Adaptación de la Costa a los Efectos del Cambio Climático. Ministerio de Agricultura, Alimentación y Medio Ambiente (MAGRAMA). Madrid, 133 pág.

Russell, N and Griggs, G., 2012: Adapting to Sea Level Rise: A Guide for California's Coastal Communities. University of California Santa Cruz. 
Sainz de Murieta, E., 2016: Environmental and Economic impacts of SeaLevel rise on the Basque Coast. Doctoral Thesis. Universidad del País Vasco.

Sea Grant, University of Southern California, 2013: Sea level Rise vulnerability Study for the City of Los Angeles.

Werner, A. D. and Simmons, C. T. (2009): Impact of Sea-Level Rise on Sea Water Intrusion in Coastal Aquifers. Ground Water, 47: 197-204. doi:10.1111/j.1745-6584.2008.00535.x.

Williams, S.J. and Gutierrez, B.T., 2009: Sea-level rise and coastal change: Causes and implications for the future of coasts and low-lying regions. Shore and Beach, 77(4), 13-21. 